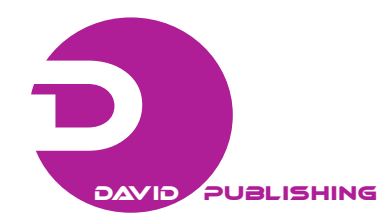

\title{
Professional Education of Quantity Surveyors for the Indonesian Construction Industry
}

\author{
Abd. Ghani Khalid ${ }^{1}$ and Martalius Peli ${ }^{2}$ \\ 1. Faculty of Built Environment, University Technology Malaysia, UTM Skudai 81310, Malaysia \\ 2. Department of Quantity Surveyor, University Bung Hatta, UBH Padang 25133, Indonesia
}

\begin{abstract}
Education and Job Training is defined as informal education in the laws of the Republic of Indonesia concerning the National Educational System in Article 26 Point 3. Education and Job Training is carried out for individuals who require knowledge, work skills, life skills, and the correct attitudes for self-development, professional development, work, independent business and continued education. In the Indonesian construction industry, the Quantity Surveyor is a common role in planning and controlling consultant firms. These firms are organized as members of National Association of Indonesian Consultants. Many firms employ architects and technical staff as Quantity Surveyors, even if they only have experience in project calculations. This has given rise to the problem of inaccurate cost projections in the construction industry. Therefore, the future of Quantity Surveyors in Indonesia hinges on the implementation of education and short courses as means of raising the skill level of the profession. These steps will help to bridge the knowledge gap between local and foreign consultants.
\end{abstract}

Key words: Education, quantity surveyor, profession.

\section{Introduction}

Today, the construction service business faces challenges in the globalised market. This new business environment presents many opportunities due to globalization, but certain factors cannot be controlled. The construction sector must not only remain competitive at a domestic level, but must also find a way to remain competitive at the international level. Similarly, the country's human resources must also stand up to global competition [1].

Therefore, the biggest challenge for the future is to improve competitiveness in all sectors. Competitiveness will depend on the human resources and technological ability available to the country [2].

The Government's role in developing the construction sector has diminished and is now handled entirely by the Institution of Development Construction Service Indonesia.

Corresponding author: Abd. Ghani Khalid, Dr., professor, research field: quantity surveying. E-mail: drdrghani@yahoo.com.
In Law No. 18 concerning Construction Service, chapter VII regarding the Role of Society, it has been noted the construction service community should fulfill its responsibility to society [3].

The community that joins the institution has some responsibilities that are noted in Article 33 Point 2:

- Perform research and development for the construction service sector;

- Provide education and training for construction;

- Conduct registrations for construction workers, which include classification, qualification, job skill and expertise certification;

- Conduct registrations for construction services;

- Encourage and enhance the role of arbitration, mediation, and expert appraisers in the field of construction service.

Information about the development of Quantity Surveying in Indonesia is lacking. One consequence is that the profession is not popular within the construction sector in Indonesia. Most Indonesian students who choose to study Quantity Surveying do their research abroad in countries such as England, 
Australia, Malaysia and Singapore. This research is not published, and as a result few people are aware of it [4].

Some articles about Quantity Surveying claim that this profession came to Indonesia around 1973-1977, and that its arrival was the result of Quantity Surveying institutions' popularity in other countries, mostly in England. In those years, there were four Quantity Surveying companies in Indonesia. Those companies had a standard measurement of building work, although it was ultimately abandoned. Later, three of the companies merged with local companies [5].

In early 1970, Quantity Surveyors were involved in a construction project in Indonesia. Many Quantity Surveying companies, such Australian and English companies, opened branches in Jakarta. They employed local workers to be technical assistants and provided training for them [6].

From the research, Dharma concludes that the development of Quantity Surveying in Indonesia is below par, for the following reasons:

- There is no local institution for Quantity Surveying education;

- There is no accreditation by the government for this profession;

- Even though this profession has come to Indonesia, it is still not sufficiently popular in the construction industry;

- So far, all the Quantity Surveying companies in Indonesia are led by foreigners;

- There is no legal regulation that requires Quantity Surveyors to be involved in government projects.

Quantity Surveying services are currently performed by architects and engineers with between four to fifteen years of experience in maintenance costing and project development. [7]

Moreover, there is only one education institution in Indonesia with a Quantity Surveying department, namely Bung Hatta University, which opened its department in 2002.
The development of the Quantity Surveying profession is still quite lacking. This problem must be resolved as soon as possible by making available more courses, training and basic knowledge about Quantity Surveying, and by promoting Quantity Surveying services to the construction industry in Indonesia.

\section{Objective}

Provide alternative methods of education for the Quantity Surveyor profession to fulfill the needs of the construction industry in Indonesia.

\section{Level of Education}

Education and Job Training is defined as informal education in the laws of the Republic of Indonesia (UU RI) No. 20 concerning the National Educational System in Article 26 Point 3. Education and Job Training is carried out for individuals who require knowledge, work skills, life skills, and the correct attitudes for self-development, professional development, work, independent business and continued education [8].

The needs of construction workers in West Sumatera are quite high, but there are no workers being certified. This certification is a must because it is the only way to qualify workers based on their competence. Every construction worker must have a Certificate of Work Skills.

There are three levels of education for Quantity Surveying:

$\begin{array}{ll}\text { Certificate } & \text { Technician } \\ \text { Diploma } & \text { Assistant Quantity Surveyor } \\ \text { Degree } & \text { Quantity Surveyor }\end{array}$

\subsection{The Requirements for Each Education Level Are as Follows}

\subsubsection{Certificate}

The participants must fulfill a minimum requirement of Grade Three in a Malaysian certificate of education (equivalent to Senior High School in Indonesia) and earn three credits in the following subjects: 
Mathematics

Chemistry

Physics

Building Construction

Economics

Accounting

Geography

Science and Technology

\subsubsection{Diploma}

The participants must fulfill a minimum requirement of Grade Two in a Malaysian certificate of education (equivalent to Senior High School in Indonesia) and earn five credits in the following subjects:

Mathematics
Physics
Chemistry
Engineering Science
Building Construction
Commerce
Geography History
Geometrical Building Drawing
Elementary Building Drawing
Elementary Survey
Accounting
Workshop Engineering
Degree

The participants must fulfill a minimum requirement of two principles in a Malaysian certificate of education (equivalent to technical secondary schools in Indonesia). The participants may be chosen from Quantity Surveying diploma graduates with a GPA (gross performance academic) of at least 2.70. Those with a GPA of less than 2.70 are required to have two years of work experience.

\subsection{Time of Education and Learning Curriculum}

Length of time required for education:

$\begin{array}{ll}\text { Certificate } & \text { One year } \\ \text { Diploma } & \text { Two years } \\ \text { Sheepskin } & \text { Three years }\end{array}$

(1) Certificate Level (one year)

The syllabus and curriculum for Quantity Surveyor education for the Certificate Level is Table 1;

(2) Diploma Level (two years)

The certificate level syllabus only covers half that of the diploma level. The additional subjects for diploma level are Table 2;

(3) Degree level (three years)

Degree level requires the same syllabus and curriculum as certificate, with the addition of the following subjects are Table 3.

Table 1 Certificate level (one year).

\begin{tabular}{llll}
\hline No & Subject group & No & Subject \\
\hline 1 & Introduction to measurement/calculation & 1 & $\begin{array}{l}\text { Engineering mathematics } \\
\text { Calculation of building quantity }\end{array}$ \\
& Introduction to construction technology & 1 & Introduction to the construction industry \\
& & 2 & $\begin{array}{l}\text { Building technology I } \\
\text { Building materials }\end{array}$ \\
3 & Introduction to building systems & 3 & Building systems I \\
4 & Introduction to economics and cost budgeting & 1 & Economics I \\
& & 2 & Estimated cost I \\
5 & Optional subjects & 1 & Computer application \\
& & 2 & Measurement of land \\
\hline
\end{tabular}


Table 2 Diploma level (two years). The certificate level syllabus only covers half that of the diploma level. The additional subjects for diploma level are:

\begin{tabular}{|c|c|c|c|}
\hline No & Subject group & No & Subject \\
\hline \multirow[t]{3}{*}{1} & $\begin{array}{l}\text { Mechanical and electrical measurement and } \\
\text { calculation }\end{array}$ & 1 & Quantity calculation \\
\hline & & 2 & Building quantity calculation I \\
\hline & & 3 & Building quantity calculation II \\
\hline \multirow[t]{2}{*}{2} & Construction technology & 1 & Building technology II \\
\hline & & 2 & Building technology III \\
\hline \multirow[t]{2}{*}{3} & Building economics & 1 & Economics II \\
\hline & & 2 & Estimated Cost II \\
\hline \multirow[t]{3}{*}{4} & Building regulations and laws & 1 & Introduction to law \\
\hline & & 2 & Contracts and tort \\
\hline & & 3 & Building contract system I \\
\hline \multirow[t]{2}{*}{5} & Professional practicum & 1 & Professional practicum I \\
\hline & & 2 & Professional practicum II \\
\hline
\end{tabular}

Table 3 Degree level (three years). Degree level requires the same syllabus and curriculum as certificate, with the addition of the following subjects.

\begin{tabular}{|c|c|c|c|}
\hline No & Subject group & No & Subject \\
\hline \multirow[t]{2}{*}{1} & Advanced measurement/ calculation & 1 & Civil works quantity calculation \\
\hline & & 2 & Mechanical and electrical quantity calculation \\
\hline \multirow[t]{2}{*}{2} & Advanced construction technology & 1 & Civil building construction \\
\hline & & 2 & Mechanical systems I \& advanced electrical \\
\hline \multirow[t]{3}{*}{3} & Advanced building economics & 1 & Building economics I \\
\hline & & 2 & Building economics II \\
\hline & & 3 & Estimated cost III \\
\hline \multirow[t]{2}{*}{4} & Advanced building regulations and laws & 1 & Building contracts I \\
\hline & & 2 & Advanced construction construct system \\
\hline \multirow[t]{2}{*}{5} & Advanced professional practicum & 1 & Professional practicum III \\
\hline & & 2 & Value engineering \\
\hline \multirow[t]{3}{*}{6} & Management & 1 & Basics of management \\
\hline & & 2 & Accounting and financial management \\
\hline & & 3 & Project management \\
\hline
\end{tabular}

\section{The Target Groups for Quantity Surveying Education in the Indonesian Construction Industry}

Based on the results of the collaboration between University Technology Malaysia and Bung Hatta University, we have determined that Quantity
Surveying education is required for the following groups in the Indonesian construction industry:

Quantity Surveying consultants with no formal education in Quantity Surveying, such as accountants, lawyers, architects, civil engineers or autodidacts;

Contractors;

Employees of consulting planner firms; 
Civil engineering, architecture, machinery or electrician diploma holders who intend to become quantity surveyors;

Students of the Quantity Surveying Diploma Programme in Bung Hatta University.

Based on these target groups, we recommend that Quantity Surveying education is offered in two stages: short-term and long-term.

\subsection{Short-term Education Proposal}

\subsubsection{Target Groups I, II and II}

Certificates of attendance can be obtained in diploma and degree levels for the modules that are appropriate with for the target groups. The number of modules required for the participants will be based on their educational background, and they will receive their diploma or degree after completing the modules.

\subsubsection{Target Group IV}

Degree level education is offered for those who have a diploma in engineering and architecture, with continued studies in Malaysia.

\subsection{Long-Term Education Proposal}

\subsubsection{Target Group IV and V}

Education in Indonesian universities is offered based on collaboration with universities in Malaysia for a degree in Quantity Surveying. This requires three years for Target Group IV, and two years for diploma graduates in Bung Hatta University.

\section{Implementation Methods}

Implementation can be performed through:

Intensive Courses and Distance Learning

Apprentice Schemes

Article-ship

\subsection{Intensive Courses and Distance Learning}

Some lectures can be done through correspondence, while others can be done through short courses. The materials for the correspondence lectures are sent via post. For short, the lectures are done in a tutorial system in each semester break (November, May and June).

The intensive course is done in Indonesia. Malaysian lecturers will come to Indonesia for periods of two weeks, three times a year. The examination will be held during a week in July after 15 modules have been delivered.

For instance, in a diploma programme, 30 weeks in a year are required for distance learning, or six weeks in a year for an intensive course in Indonesia. In Malaysia, the university semester break occurs in November, May and June. Thus, study can be completed in three years, which is a year longer than the usual time needed for a diploma.

Twinning programmes between Indonesia and Malaysia can facilitate these studies. The Malaysian party would help in arranging the curriculum and the syllabus, as well as conducting lectures for universities in Indonesia. The Indonesian party would be responsible for handling the needs of the lectures.

These studies would be module-based, and each module is planned for 60 hours. Once completed, students would receive the diploma or degree of the respective Indonesian or Malaysian educational institution.

Quantity Surveyor studies can also be done through a split method programme involving cooperation between Indonesia and Malaysia. Half of the programme would be held in Indonesia with the other half held in Malaysia. For example, a diploma-level, a year is done in Indonesia and two more years is in Malaysia.

Split programmes also can be applied for Degree program in Bung Hatta University and the students can continue their study in UTM (University Technology Malaysia) for two years.

\subsubsection{Apprentice Scheme}

The apprentice scheme can also be done while studying. Participants in this scheme can get a job in Quantity Surveyor firms or in government offices with Quantity Surveyors. By night, they are required to 
learn about Quantity Surveying in Malaysian universities.

This type of education can be completed in two years for a degree programme, or four years for a diploma programme.

There are two alternative apprentice schemes:

Participants can study modules in Indonesia if government or private organisations are willing to cooperate with Malaysia;

Participants can also get a job in the Malaysian Public Works Department, or in Quantity Surveyor firms, after completing modules in Malaysia.

\subsubsection{Article-ship}

Thanks to the cooperation of UTM (Malaysia), employees of Quantity Surveyor firms or Consultant Planners in Indonesia can take the professional testing offered by the Institute for Indonesian Regional Development Construction Service. The Regional Development Construction Services Institute also has courses for those who wish to take the tests. As an alternative, they also can choose to study modules and subjects.

\section{Conclusions}

We hope that this paper gives a clear explanation about the educational methods for Quantity Surveying. We also hope that this paper offers solutions for some of the problems of professional education for Quantity Surveying, with an eye toward its development. This will allow construction workers with no educational background to join this occupation, which will help it to quickly develop in Indonesia.

Lastly, it is our hope that this paper will receive a positive response from private companies as well as the Indonesian government. That is all.

\section{References}

[1] D. A. Rondinelli, Building Project for Integrated Management, Management Handbook Bumi Aksara, Jakarta, 1990.

[2] M. A. Dadan, Construction services enters a new round, Journal of the Institute for Government Procurement of Goods/Services, Jakarta, 2010.

[3] Law of the Republic of Indonesia No. 18, Construction Services, 1999.

[4] D. Angkasa, Role of Professional Quantity Surveyor in the Construction Industry in Indonesia, Seminar Quantity Surveyor in Padang, West Sumatera, 2004.

[5] S. Wibowo, Quantity surveyor and estimator, Construction magazine, Jakarta, Jan. 1998.

[6] D. Angkasa, Development profession of quantity surveyor in Indonesia, Thesis Postgraduate QS University Technology Malaysia (UTM), 1996.

[7] P. Martalius, The role of quantity surveyor in construction industry in Indonesia, in: International Conference of Construction Industry UBH-Padang West Sumatera, 2006.

[8] Law of the Republic of Indonesia No. 20, on National Education System, 2003. 